\title{
COMBINATION LASER THERAPY FOR EPIRETINAL MEMBRANE: A PHYSICO-MATHEMATICAL MODEL
}

Takhchidi KP',2, Zheltov GI ${ }^{4}$, Kachalina $\mathrm{GF}^{2}$, Kasminina TA², Tebina $\mathrm{EP}^{3} \bowtie$

1 Pirogov Russian National Research Medical University, Moscow, Russia

${ }^{2}$ Research Center for Ophthalmology, Pirogov Russian National Research Medical University, Moscow, Russia

${ }^{3}$ Faculty of Pediatrics, Pirogov Russian National Research Medical University, Moscow, Russia

${ }^{4}$ Stepanov Institute of Physics, Minsk, Belarus

An epiretinal membrane (ERM) is a product of abnormal cell proliferation on the inner surface of the retina and at the vitreomacular interface. Laser therapy is an interesting modality for treating pathologies of the vitreomacular interface. The wise choice of laser settings (wavelength, exposure time, power) minimizes damage to the retina and ensures a good therapeutic effect. This could be a serious impetus to the development and refinement of laser technologies for treating ERM. This work investigates the biophysical response of structural retinal components, including the dynamics of temperatures and acoustic oscillations, protein denaturation, and stimulation of tissue regeneration, to a quasi-cw laser beam and a subsequent series of laser micropulses. The manuscript also analyzes the mechanisms underlying the therapeutic effect of the proposed laser therapy in patients with ERM.

Keywords: epiretinal membrane, subthreshold micropulse laser photocoagulation, combination laser therapy, optical coherence tomography

Author contribution: Takhchidi KP and Kachalina GF conceived and designed the study; Tebina EP collected and analyzed the data; Kasminina TA performed laser therapy; Zheltov Gl, Kasminina TA, and Tebina EP wrote the manuscript; Zheltov Gl and Takhchidi KP revised the manuscript.

Compliance with ethical standards: the study was approved by Russian National Research Medical University (Protocol № 160 of December 19, 2016).

$\bowtie$ Correspondence should be addressed: Ekaterina P. Tebina

Volokolamskoe shosse 30, bl. 2, 123182; ekaterinatebina@mail.ru

Received: 01.03.2019 Accepted: 15.03.2019 Published online: 30.04.2019

DOI: 10.24075/brsmu.2019.032

\section{ТЕХНОЛОГИЯ КОМБИНИРОВАННОГО ЛАЗЕРНОГО ЛЕЧЕНИЯ ЭПИРЕТИНАЛЬНОГО ФИБРОЗА: ФИЗИКО-МАТЕМАТИЧЕСКАЯ МОДЕЛЬ}

Х. П. Тахчиди ${ }^{1,2}$, Г. И. Желтов ${ }^{4}$, Г. Ф. Качалина ${ }^{2}$, Т. А. Касмынина ${ }^{2}$ Е. П. Тебина ${ }^{\square}$

${ }^{1}$ Российский национальный исследовательский медицинский университет имени Н. И. Пирогова, Москва, Россия

${ }^{2}$ Научно-исследовательский центр офтальмологии, Российский национальный исследовательский медицинский университет имени Н. И. Пирогова, Москва, Россия

${ }^{3}$ Педиатрический факультет, Российский национальный исследовательский медицинский университет имени Н. И. Пирогова, Москва, Россия

${ }^{4}$ Институт физики имени Б. И. Степанова НАН Беларуси, Минск, Беларусь

\begin{abstract}
Эпиретинальная мембрана (ЭРМ) возникает в результате пролиферативно-дистрофического процесса во внутренних слоях сетчатки и витреомакулярном интерфейсе. Особый интерес в лечении витреоретинальной патологии представляет применение лазерного излучения в макулярной зоне. При адекватном выборе режимов облучения (длины волны, длительности экспозиции и мощности излучения) лечебный эффект достигается при минимальном повреждающем действии на структуры сенсорной сетчатки. Этот фактор явился серьезным стимулом для развития и совершенствования лазерных технологий в лечении ЭРМ. В представленной работе проведен анализ биофизического отклика структурных элементов сетчатки (динамики температурных и акустических полей, термоденатурация, стимуляция репаративных процессов) при последовательном воздействии лазерного квазинепрерывного излучения и серии микроимпульсов с дальнейшей оценкой основных механизмов лечебного эффекта разработанной комбинированной лазерной технологии у пациентов с ЭРМ.
\end{abstract}

Ключевые слова: эпиретинальный фиброз, субпороговое микроимпульсное лазерное воздействие, комбинированная лазерная технология, оптическая когерентная томография

Информация о вкладе авторов: Х. П. Тахчиди, Г. Ф. Качалина - концепция и дизайн исследования; Е. П. Тебина - сбор и обработка материала; Т. А. Касмынина - лазерное лечение пациента; Г. И. Желтов, Т. А. Касмынина, Е. П. Тебина — написание текста; Г. И. Желтов, Х. П. Тахчиди редактирование.

Соблюдение этических стандартов: исследование одобрено этическим комитетом РНИМУ имени Н. И. Пирогова (протокол № 160 от 19 декабря 2016 г.).

$\triangle$ Для корреспонденции: Екатерина Павловна Тебина

Волоколамское шоссе, д. 30, корп. 2, 123182; ekaterinatebina@mail.ru

Статья получена: 01.03.2019 Статья принята к печати: 15.03.2019 Опубликована онлайн: 30.04.2019

DOI: $10.24075 /$ vrgmu.2019.032

Ever more people across the world are affected by fibrotic scarring of the retina that can cause significant visual impairment or even blindness [1]. An epiretinal membrane (ERM) is a product of abnormal cell proliferation on the inner surface of the retina and at the vitreomacular interface [2]. It is a fibrous tissue that contracts, causing the retina to pucker and promoting formation of a macular hole [2, 3].
The major contributors to this ocular disorder are posterior vitreous detachment (PVD), the anatomy of the internal limiting membrane (ILM), which has microscopic pores, and abnormal blood supply to the macula [4-6]. According to the literature, ERM is constituted by various cell types, including glial cells (Müller cells, astrocytes and microglial cells), hyalocytes, macrophages, retinal pigment epithelial cells, and fibroblasts 
[7-8]. ERM formation is initiated when these cells, regardless of their origin, transdifferentiate into myofibroblast-like cells that abundantly secrete transforming growth factor beta 1 , causing the membrane to contract [9-10]. The most intense cell proliferation takes place long before ERM becomes symptomatic. Once the membrane has been formed on the retinal surface, cell proliferation stops [11].

In the early stages of the disease, cell proliferation can be inhibited using a variety of different methods, such as intravitreal injections of high doses of glucocorticoids, radiation therapy or administration of cytostatic agents [12]. These methods, however, have a high risk of adverse effects and therefore are not popular in clinical practice. At present, two strategies are normally used in patients with ERM: surgery to remove the membrane (vitrectomy) and monitoring without treatment [13].

In spite of significant advances in the understanding of the mechanisms underlying ERM formation, the conditions under which vitreoretinal cells transdifferentiate into myofibroblasts are unknown. It is also unclear whether surgical removal of the membrane should be performed in asymptomatic patients or can be safely delayed until visual acuity starts to deteriorate or a patient develops metamorphopsia. Unfortunately, there is no guarantee that the lost vision will be restored after surgery. In addition, post-operative relapses are not a rare thing [12].

Laser therapy is an interesting modality for treating pathologies of the vitreomacular interface [14-15]. The wise choice of laser settings (wavelength, exposure time, power) minimizes damage to the retina and ensures a good therapeutic effect [16-17]. Recently, the authors of this work have patented a new, clinically tested method for treating patients with early stages of preretinal macular fibrosis; the method is a combination of selective photocoagulation of the ERM by a yellow laser and subsequent stimulation of tissue regeneration by a series of subthreshold laser micro-pulses [18]. Such laser therapy induces ERM regression, improves visual acuity and increases light sensitivity of the retina.

Further evolution and clinical application of the proposed method will largely depend on the understanding of its therapeutic mechanisms. Research into biological and physical interactions between the laser beam and structural retinal components can significantly expand our knowledge in this field. a useful tool here is mathematical modeling that accounts for the laser settings needed to achieve a therapeutic effect [17-20].

We have developed a physico-mathematical model that predicts biophysical effects of laser exposure on retinal tissues. The aim of this study was to investigate and analyze the biophysical response (the dynamics of temperatures and acoustic oscillations, protein denaturation, and stimulation of tissue regeneration) of structural retinal components to a quasi-continuous-wave laser beam and a subsequenta series of laser micropulses.

\section{METHODS}

Based on the experiments conducted in animal models (rabbits and primates), we determined the conditions required to induce local changes to intact chorioretinal tissue by laser radiation and identified the underlying mechanisms $[17,19]$.

These findings, coupled with the knowledge of spectral, optical and physical properties of intraocular structures, laid a basis for developing a physical model of the interactions between the laser beam and ocular fundus tissues (Fig.1) [19]. The mathematical description of this model was used to determine and optimize laser settings needed to preserve the

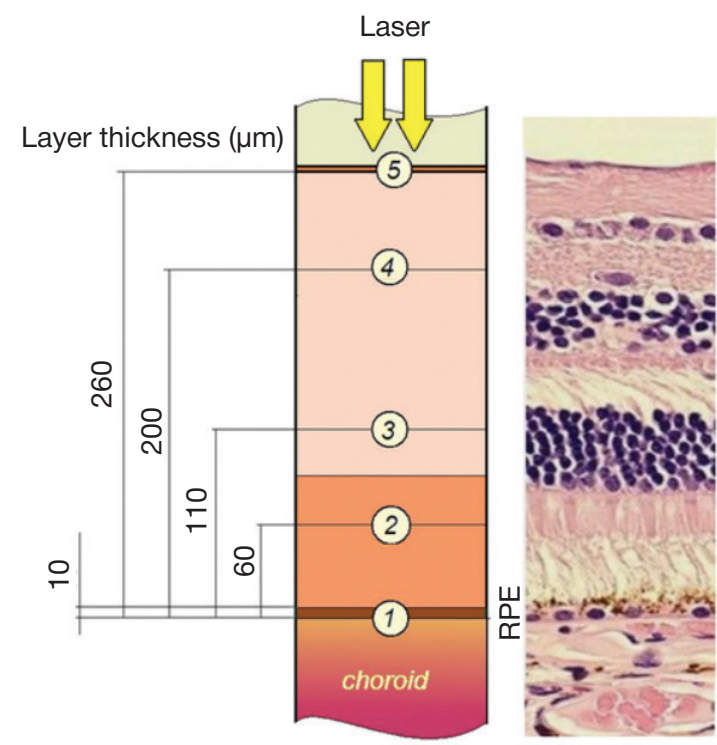

Fig. 1. A topographic representation of the chorioretinal complex. 1- the retinal pigment epithelium (10 $\mu \mathrm{m}$ in thickness), 2 - the layer of photoreceptors $(60 \mu \mathrm{m}), 3$ - the outer nuclear layer $(110 \mu \mathrm{m}), 4$ - the inner nuclear layer $(200 \mu \mathrm{m}), 5$ - the inner limiting membrane $(260 \mu \mathrm{m})$

healthy structure of the retina and inhibit cell proliferation in the early stages of ERM.

The model is a multilayer system in which the geometrical dimensions and physical/optical properties of the layers correspond to those of major anatomical structures of the ocular fundus [21]. It accounts for the patterns of laser beam propagation in the anterior part of the eye, light absorption and scattering in the neuroepithelium and the choroid, and some other factors, including the presence of blood flow in the choroid with a speed gradient in the zone extending from Bruch's membrane to the sclera. Laser beam energy is absorbed by melanin granules and converts into heat. In the model, the optical properties of the intraocular structures located in the anterior part of the eyeball corresponded to those found in individuals above 40 years of age. The concentration of the pigment in the retinal pigment epithelium (RPE) was assumed to be 0.2 , which is a typical concentration for a Caucasian patient.

The proposed method for treating ERM uses a combination of grid laser photocoagulation (577 nm wavelength, power of $50 \mathrm{~mW}$, pulse duration of $0.05 \mathrm{~s}$, spot size of $100 \mu \mathrm{m}$, distance between the coagulates of $150 \mu \mathrm{m}$ ) and subthreshold laser micropulses $(577 \mathrm{~nm}$ wavelength, burst length of $30 \mathrm{~ms}$, micropulse duration of $50 \mu$ s, duty cycle of $4.7 \%$, repetition rate of $1,000 \mathrm{~Hz}$, spot size of $100 \mu \mathrm{m}$, power of $50 \mathrm{~mW}$ ) [18]. These parameters were used as initial conditions for further computations.

The distribution of temperatures in the chorioretinal complex was determined by a numerical solution of a two-dimensional $\rho(Z) \operatorname{Cp}(Z) \frac{\partial T}{\partial t}+F^{(k)}(U, V)=\frac{1}{r} \frac{\partial}{\partial r}\left[r \varkappa(Z) \frac{\partial T}{\partial r}\right]+\frac{\partial}{\partial Z}\left[\varkappa(Z) \frac{\partial T}{\partial Z}\right]+Q(t) q(r, Z, k, s) ;$

$$
q_{i}(r, Z)=\frac{E_{i-1}\left(k_{i}+s_{i}\right) R_{i-1}^{2}}{r_{i-1}^{2}} \exp \left[-k_{i}\left(Z-Z_{i}\right)-\frac{r^{2}}{r_{s}^{2}}\right]
$$

Fig. 2. The heat equation for layer $i$ of the model. $T(r, Z, t)$ is a temperature rise above the physiological norm $\left(37^{\circ} \mathrm{C}\right) ; C p(Z), p(Z), x(Z)$, are specific heat capacity, density and thermal conductivity, respectively; $Q(t)$ is time-dependent intensity of the absorbed radiation; $q$ is volumetric heat generation, $k$ and $s$ are light absorption and scattering; $F^{(k)}$ is a function determined by the rates of radial $(V)$ and axial $(U)$ convective heat transfer; $R_{i, 1}$ and $E_{i, 1}$ are spot size (exp (-1)) and Gaussian beam irradiance at the interface between two adjacent layers 
heat equation [19, 22] Fig. 2 shows the equation applied to describe each layer of the model. The size of the irradiated area of the pigment epithelium was assumed to be $100 \mu \mathrm{m}$, corresponding to the spot size. Radial irradiance distribution was considered to be Gaussian. The laser wavelength was $577 \mathrm{~nm}$. Given the age of patients and the typical optical loss in the anterior part of the eye, the power of the laser beam absorbed by the chorioretinal complex was assumed to be $0.035 \mathrm{~W}$ $[21,23]$. Then, given that the beam radius $R$ was $50 \mu \mathrm{m}$, irradiance received by the inner limiting membrane was $E \approx 4.5 \cdot 10^{6} \mathrm{~W} / \mathrm{m}^{2}$. The pulse shape, which defines the $Q(t)$ function, was rectangular.

\section{RESULTS AND DISCUSSION}

Below, we describe the temperature profile of the retina irradiated by laser pulses with the parameters specified above. The distribution of temperatures along the laser beam axis $(r=0)$ is shown in Fig 3. Curve 1 in Fig. 3 reflects the degree of tissue heating $(T(Z, r=0))$ by the end of the pulse. The averaged value $k_{\mathrm{RPE}}$ of yellow light absorption by RPE is $3-10^{-4} \mathrm{~m}^{-1}$. About $30 \%$ of energy of the incident light is absorbed by pigment granules of RPE, whereas $70 \%$ propagates further into the capillaries and the choroid, and is absorbed by blood hemoglobin, causing tissue heating (Curve 1 in Fig. 3).

The part of the choroid adjacent to RPE is heated to the temperatures that exceed that of RPE. This area acts as a buffer, ensuring propagation of heat to the inner layers of the neuroepithelium and preventing the heat flow from traveling deeper into the choroid. Attenuated heat reaches the internal limiting membrane $0.3 \mathrm{~s}$ after the onset of exposure. Cooling continues for a few more seconds, stimulating photothermal tissue regeneration in all structural components of the neuroepithelium.

The relatively low absorption value $\mathrm{k}_{\mathrm{RPE}}$ (in comparison with $\mathrm{k}_{\mathrm{i}}$ of the green spectrum) means that the degree of a patient's retinal pigmentation has only a mild effect on the damage threshold. This fact, as well as the lack of absorption of the yellow spectrum by macular pigments, makes the proposed treatment modality especially beneficial for patients $[20,21,24]$.

Fig. 4 shows the dynamics of tissue cooling and heating $T(t, Z, r=0)$ in the retinal layers lying in the proximity to the laser beam axis; the colored areas on the graph indicate a dominating optical and thermal effect of laser radiation on the retinal tissues.

Exposure to 0.05-second-long laser pulses results in a temperature rise by about $35^{\circ} \mathrm{C}$ and causes denaturation (coagulation) of RPE and proteins of the retina [19, 25]. Under such conditions, about $70 \%$ of the protein molecules undergo irreversible damage; therefore, the temperature specified above is considered to be a critical threshold. A temperature rise above the threshold value aggravates damage to tissues. In Fig. 3. The area heated above the threshold value is designated as the area of denaturation.

Laser-induced heating of tissue by 10 to $25{ }^{\circ} \mathrm{C}$ does not cause irreversible damage, but instead has a therapeutic effect that involves stimulation of retinal tissue regeneration [26]. In the picture, this area is referred to as the area of photothermal stimulation.

Laser-induced heating of tissue by 25 to $35{ }^{\circ} \mathrm{C}$ is characterized by a competition between tissue destruction and regeneration. It is difficult to tell which process is dominating; mathematical modelling cannot give an accurate answer. In the figure, this area is termed the staging area.
Summing up, our model predicts denaturation of RPE protein structures and total or partial local coagulation of the retina in the described irradiation modes (Curve 1, Fig. 4).

The most pronounced photothermal therapeutic effect on the tissues is observed in the area of inner and outer nuclear layers and part of the inner plexiform layer and ganglia. Here, exposure time is determined by the rate of tissue cooling. It takes the tissues a few seconds to cool down, which is many times longer than the duration of irradiation itself. In the retinal region close to the internal limiting membrane where ERM is formed, the probability of photothermal stimulation remains finite but still decreases considerably (see Curve 5 in Fig. 4). This means that laser-induced direct stimulation of ERM growth is highly unlikely. Figure 5 shows 10,25 and $35^{\circ} \mathrm{C}$ isotherms in the $r, Z$ plane; they are given to illustrate radial distribution of temperatures under the studied conditions. The temperature ranges correspond to the data provided in Fig. 3.

Thus, the reduction of pulse duration down to $0.03 \mathrm{~s}$ shifts the zone of effective photothermal stimulation closer toward the inner nuclear layer. By contrast, an increase in the pulse

$\mathrm{T}(\mathrm{Z})$; heating $0.05 \mathrm{~s}$, cooling $0.25 \mathrm{~s}$

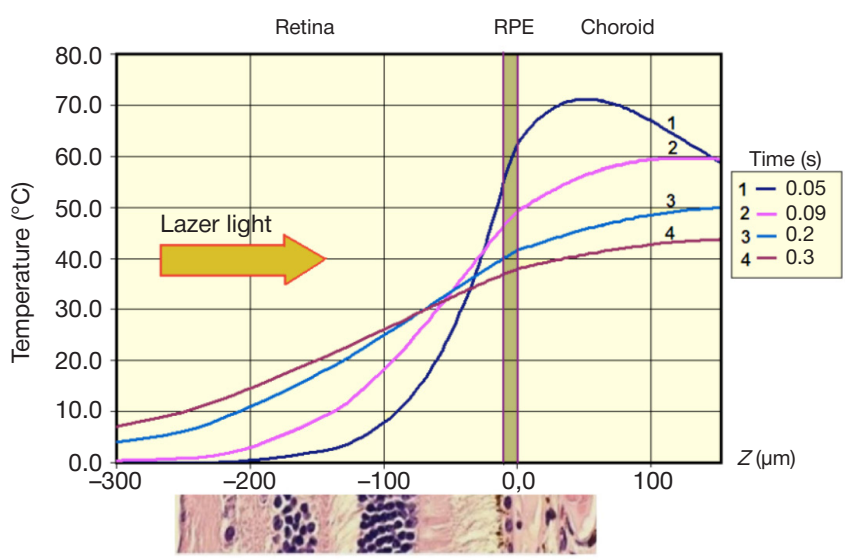

Fig. 3. A relationship between the degree of retinal tissue heating and the thickness $Z(r=0)$ of the chorioretinal complex by the end of the pulse, $t=0.05 \mathrm{~s}$ (1) and during tissue cooling $0.09 \mathrm{~s} \mathrm{(2),} 0.2 \mathrm{~s} \mathrm{(3)}$ and $0.3 \mathrm{~s}(4)$ after the onset of irradiation

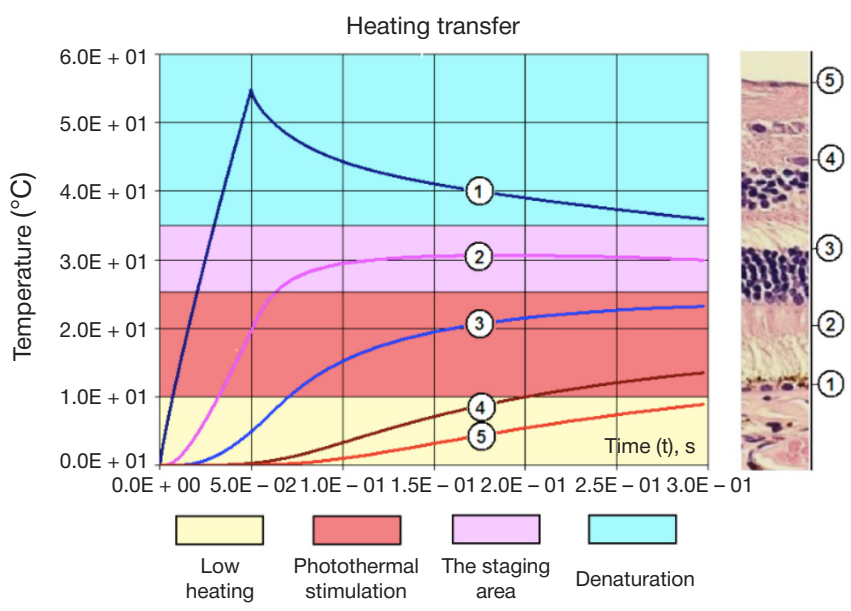

Fig. 4. Heating and cooling dynamics $T\left(t, Z_{i}, r=0\right)$ in the retinal zones corresponding to the thickness $Z_{i}$ of layer $\mathbf{1}$ (the retinal pigment epithelium, $10 \mu \mathrm{m}$ ), 2 (the layer of photoreceptors, $60 \mu \mathrm{m}$ ), 3 (the outer nuclear layer, $110 \mu \mathrm{m}$ ), 4 (the inner nuclear layer, $200 \mu \mathrm{m}$ ), and $\mathbf{5}$ (the inner limiting membrane, $260 \mu \mathrm{m})$. The blue color marks the area of irreversible protein denaturation at temperatures that exceed the physiological norm by $25^{\circ} \mathrm{C}$. The area of photothermal stimulation with the temperature rise ranging between 10 and $25^{\circ} \mathrm{C}$ is shown in red; at these temperatures the therapeutic effect is achieved, and irreversible protein denaturation is almost negligible. The staging area marked in purple is where tissue regeneration stops and irreversible protein denaturation begins 
length up to $0.07 \mathrm{~s}$ promotes heating of deeper layers and ERM and, therefore, can directly stimulate its growth.

\section{Thermomechanical effects of laser micropulses on biological tissue}

More intricate mathematical modeling is required to predict the thermomechanical effect of short laser pulses on biological tissue [27, 28]. Short pulses induce mechanical (acoustic) oscillations. For yellow laser pulses of $50 \mu$ in length generated at $50 \mathrm{~mW}$, the amplitude of mechanical oscillations approximates decimal fractions of a bar ( 1 bar $\approx 1$ atm). Mechanical (cavitation-induced) damage to biological tissue occurs above the threshold value of 30-40 bar [28, 29].

At power set to $50 \mathrm{~mW}$ and a pulse duration of $50 \mu \mathrm{s}$, the temperature rise in the hottest spot of the pigment epithelium (along the beam axis) does not exceed $0.15^{\circ} \mathrm{C}$. Given that the repetition rate is $1,000 \mathrm{~Hz}$, the next short pulse arrives in $10^{-3} \mathrm{~s}$ (1 ms). Regardless of the degree of heating, cooling occurs slowly. RPE does not cool down completely in the intervals between the pulses, and, therefore, accumulates heat from pulse to pulse. The interval of $0.03 \mathrm{~s}$ is enough to ensure a steady temperature rise of $2{ }^{\circ} \mathrm{C}$. The critical rise above the physiological temperature is $30-35^{\circ} \mathrm{C}$. Generally, the heating and cooling of the retina follow the patterns shown in Fig. 2-4. However, in this case the temperature rise is 20 times lower.

Thus, at the selected stimulation mode, the thermomechanical effect of laser radiation on retinal tissues is very mild. We can almost rule out the probability of inducing thermal damage to the neuroepithelium. The therapeutic effect is determined by the thermomechanical impact of low-intensity laser radiation with the specified parameters.

The efficacy and safety of the proposed method can be illustrated by the following clinical case. Patient I., 68 years of age, presented with complains of decreased visual acuity and distorted vision in the right eye. During the examination, uncorrected visual acuity was 0.6; best-corrected visual acuity was 1.0. Biomicroscopy of the right eye revealed clear optical media. The optic disc was pale-pink, with sharp edges. a "cellophane" membrane was noticed in the macular zone.
The patient underwent multispectral imaging of the retina in the Multicolor mode with the following monochromatic filters: blue (BR; $488 \mathrm{~nm}$ ), green (GR; $515 \mathrm{~nm}$ ) and infrared (IR; $820 \mathrm{~nm})$; spectral optical coherence tomography (SOCT), En Face optical coherence tomography angiography (OCT-A) (Spectralis OCT; Heidelberg Engineering, Inc., Germany) and microperimetry (MAIA, CenterVue; Italy). Multispectral imaging revealed the yellow-green foci indicative of ERM prominence (Fig. 6A). Measured by microperimetry, the average light sensitivity of the central retina was $26,3 \mathrm{~dB}$ (Fig. 6B). An OCT scan through the fovea discovered a hyperreflective line intimately associated with the internal limiting membrane; the foveal pit was flat. The thickness of the central retina was increased $(257 \mu \mathrm{m})$. The outer limiting membrane, the junction between the inner and outer photoreceptor segments, the retinal pigment epithelium, and the choroid were intact (Fig. 6C).

Based on those findings, the patient was diagnosed with stage 0-1 preretinal macular fibrosis of the right eye. The patient was offered to undergo laser therapy: a combination of grid laser photocoagulation at $577 \mathrm{~nm}$ wavelength and subthreshold laser micropulses at $577 \mathrm{~nm}$ wavelength (3 sessions, separated by a month).

The first stage of treatment included grid laser photocoagulation of the retina excluding the avascular zone. The following laser settings were applied: wavelength of $577 \mathrm{~nm}$, power of $50 \mathrm{~mW}$, pulse duration of $0.05 \mathrm{~s}$, spot size of $100 \mu \mathrm{m}$, distance between the coagulated spots of $150 \mu \mathrm{m}$. Two weeks after the session, a follow-up examination was conducted; uncorrected visual acuity improved to 0.7 , best-corrected visual acuity was 1.0.

Multispectral imaging in the Multicolor mode revealed thinner, blurred ERM contours along its entire length, apart from the avascular zones, where coagulation spots remained (Fig. 7A). Measured by microperimetry, the average light sensitivity of the retina was $26.5 \mathrm{~dB}$ (Fig.7 B). SOCT visualized the flat fovea and the same hyperreflective line fused to the retinal surface (ERM). The thickness of the central retina had decreased to $253 \mu \mathrm{m}$. The outer limiting membrane, the junction between the inner and outer photoreceptor segments, the choroid, and the retinal pigment epithelium were intact (Fig. 7C).

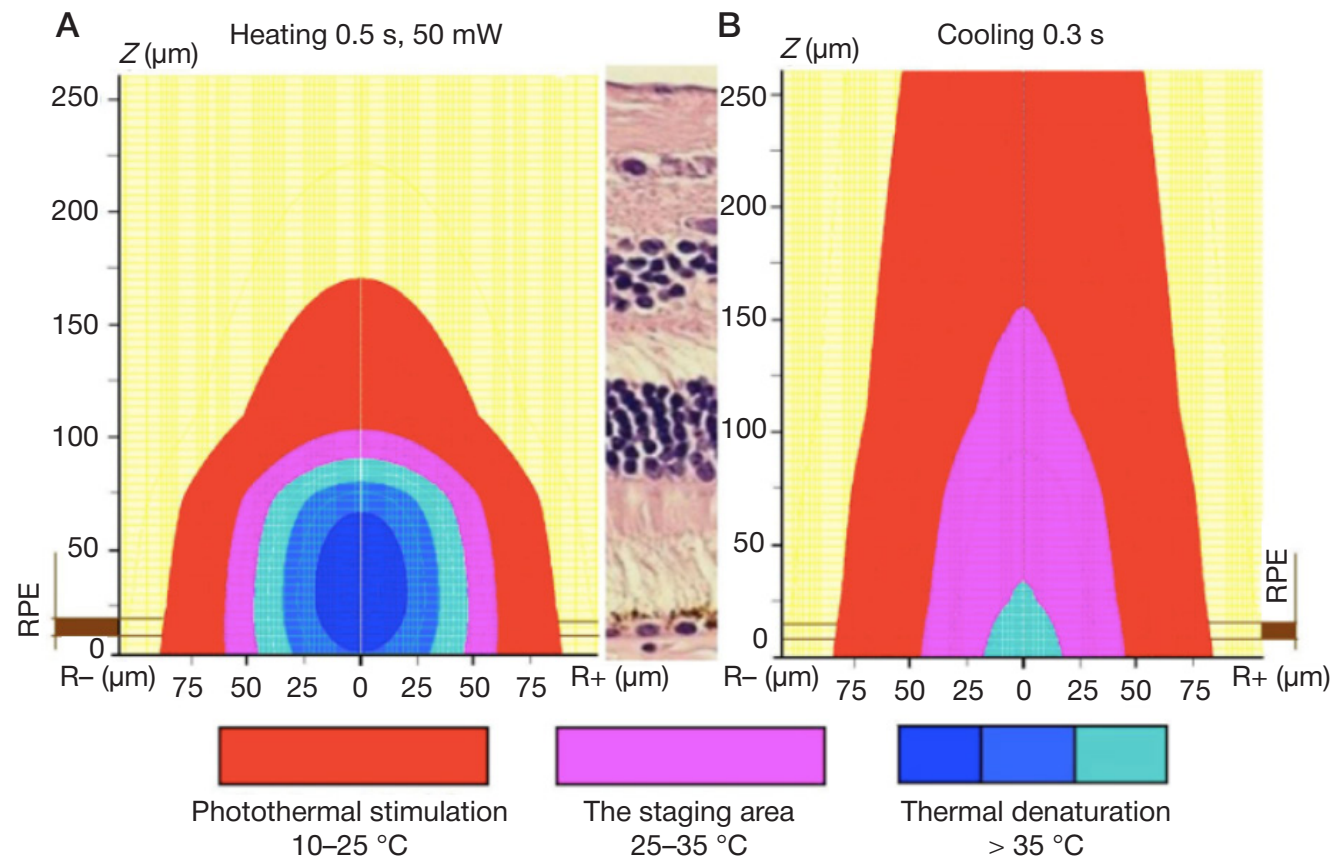

Fig. 5. Distribution of temperatures $T(r, Z)$ in retinal tissues during heating $(\mathbf{A})$ and cooling $(\mathbf{B})$ by the end of the laser pulse $(t=0.05 \mathrm{~s})$ and at $t=0.3 \mathrm{~s}(\mathrm{cooling})$ in the sagittal plane 
Six months after completing the second part of the treatment course that included 3 sessions of subthreshold laser micropulses (with a month interval between each two sessions), the patient underwent a follow-up examination; uncorrected visual acuity became 0.9 , whereas best-corrected acuity was 1.0.

Multispectral imaging conducted in the Multicolor mode revealed regression of the central part of ERM (Fig. 8A). Measured by microperimetry, the average light sensitivity of the retina $26.6 \mathrm{~dB}$ (Fig. 8B). SOCT images revealed formation of the foveal pit; the thickness of the central retina had decreased to $246 \mu \mathrm{m}$. The outer limiting membrane, the junction between the inner and outer photoreceptor segments, the choroid, and the retinal pigment epithelium were intact (Fig. 8C). Postoperative SOCT images demonstrated that coagulation sites corresponded to the sites of photothermal stimulation showed in Figures 3 and 4.

\section{CONCLUSIONS}

We have developed a new laser combination therapy for treating the early stages of ERM. The first clinical tests have confirmed its efficacy and safety. Mathematical modeling allowed us to study the dynamics of thermomechanical effects of laser radiation on the structural components of the neuroepithelium during the exposure. We have also described the major mechanisms underlying the therapeutic effect of laser radiation in patients with ERM.
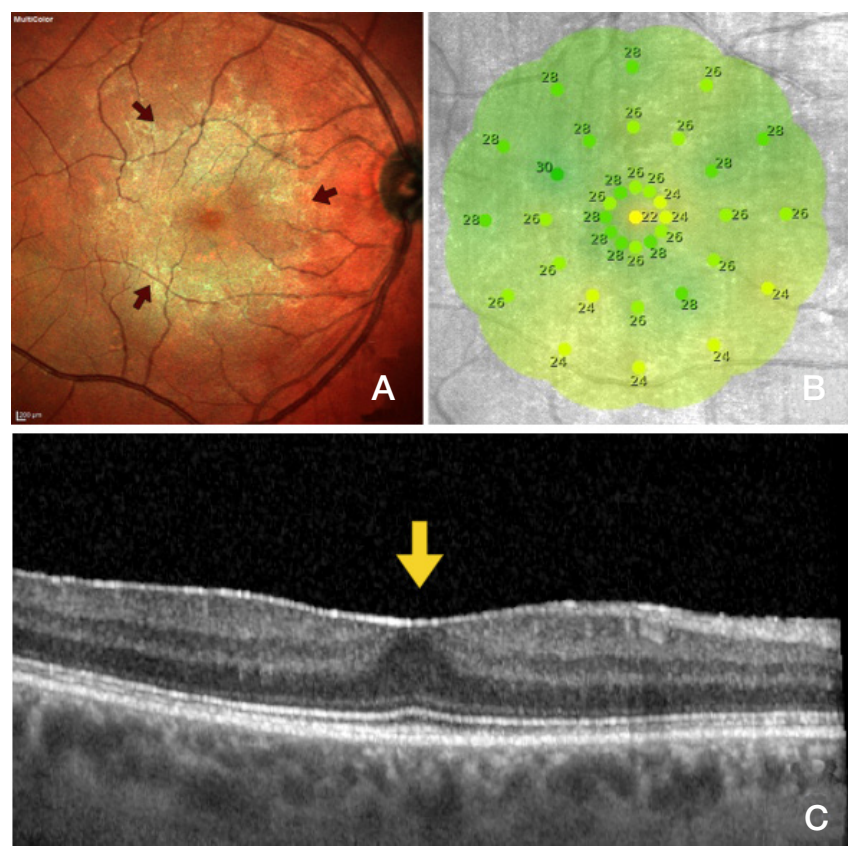

Fig. 6. The ocular fundus before the treatment: (A) a Multicolor photo showing the surface and the boundaries of ERM in yellow and green (marked by red arrows); (B) microperimetry of the macular zone, the average light sensitivity was $26.3 \mathrm{~dB}$; (C) SOCT of the retinal membrane surface showing a hyperreflective line fused to the inner limiting membrane; the foveal pit is flat (the yellow arrow); the thickness of the central retina is $257 \mu \mathrm{m}(\mathrm{c})$

\section{References}

1. Leask A, Abraham D. TGF- $\beta$ signaling and the fibrotic response. The FASEB Journal. 2004; 18 (7): 816-27.

2. Kachalina GF, Kasminina TA, Ivanova EV, Kuranova OI. Laser treatment of transudative maculopathy caused by the epiretinal
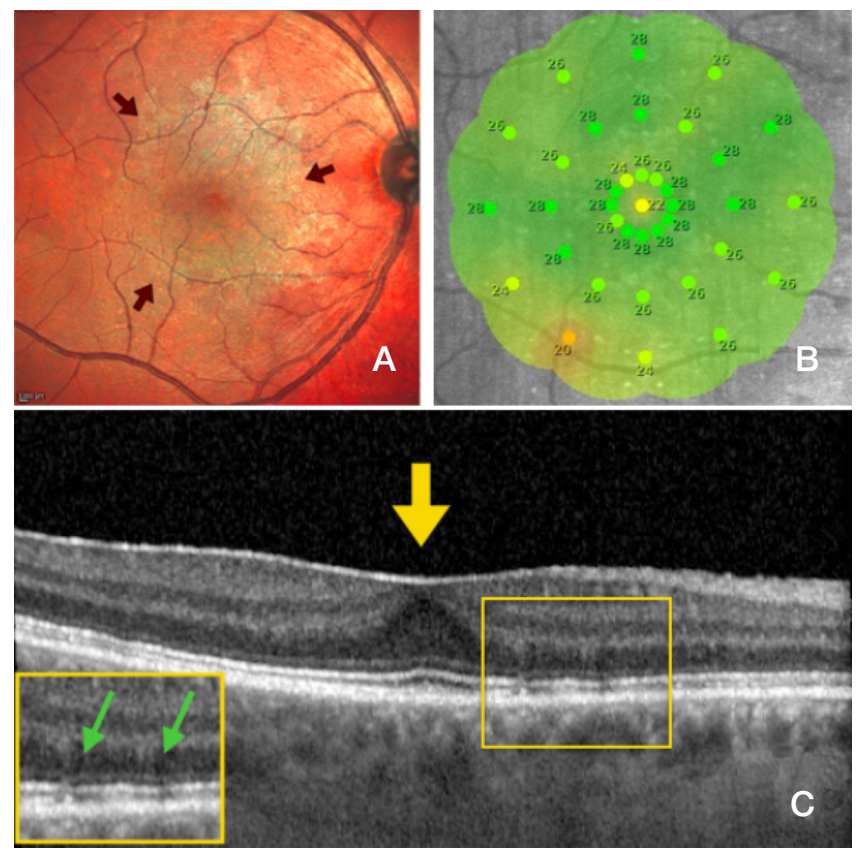

Fig. 7. The ocular fundus after the first session of grid laser photocoagulation; (A) a Multicolor photo of the fundus shows thinner, blurred ERM contours in the macular zone (the red arrow); (B) microperimetry of the macular zone: the average light sensitivity is $26.5 \mathrm{Db}$; (C) SOCT reveals a hyperreflective line fused to ILM, the foveal pit is flat (the yellow arrow), the thickness of the central retina is slightly decreased $(253 \mu \mathrm{m})$. The green arrow on the OCT image marks laser coagulates; the retinal layers are structurally unchanged

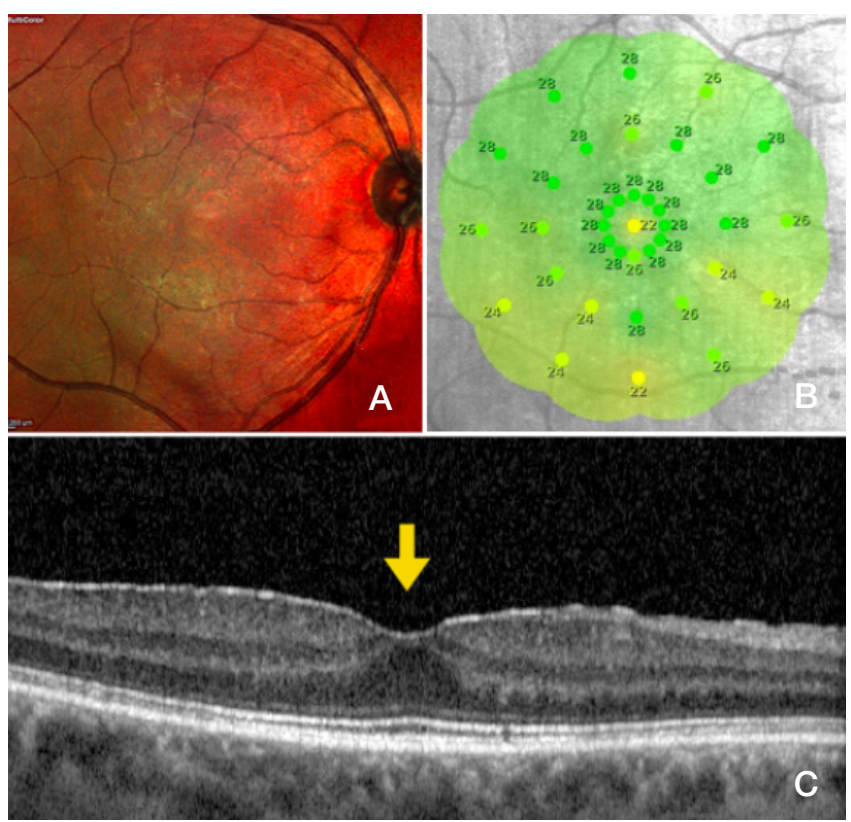

Fig. 8. The ocular fundus after the completed treatment course: (A) a Multicolor photo of the fundus showing ERM regression; (B) microperimetry: the average light sensitivity is $26.6 \mathrm{~dB}$; (C) an OCT image showing a thinner hyperreflective line (ERM) and formation of the foveal pit (the yellow arrow); the thickness of the central retina is $246 \mu \mathrm{m}$ membrane. Modern technologies of treatment of vitreoretinal pathology. S. Fyodorov Eye Microsurgery Federal State Institution. 2012; 94-6.

3. Patronas M, Kroll A, Lou P, Ryan E. a Review of Vitreoretinal 
Interface Pathology. International Ophthalmology Clinics. 2009; 49 (1): 133-43.

4. Ponomareva EN, Kazaryan AA. The electroretinogram and the pattern of optical coherence tomography in patients with idiopathic epiretinal membrane. Russian Ophthalmological Journal. 2013; (2): 66-9.

5. Guidry C. The role of Müller cells in fibrocontractive retinal disorders. Progress in Retinal and Eye Research. 2005; 24 (1): 75-86.

6. Harada C, Mitamura Y, Harada T. The role of cytokines and trophic factors in epiretinal membranes: Involvement of signal transduction in glial cells. Progress in Retinal and Eye Research. 2006; 25 (2): 149-64.

7. Zhao F, Gandorfer A, Haritoglou C, Scheler R, Schaumberger M, Kampik a et al. Epiretinal Cell Proliferation in Macular Pucker and Vitreomacular Traction Syndrome. Retina. 2013; 33 (1): 77-88.

8. Joshi M, Agrawal S, Christoforidis J. Inflammatory Mechanisms of Idiopathic Epiretinal Membrane Formation. Mediators of Inflammation. 2013; (2013): 1-6.

9. Hinz B, Phan SH, Thannickal VJ, et al. The myofibroblast: one function, multiple origins. Am J Pathol. 2007; (170): 1807-16.

10. Zakharov VD, Borzenok SA, Gorshkov IM, Kolesnik SV, Kolesnik Al, Miridonova AV. Etiological and pathogenetic aspects and role of vitreoretinal interface structures in idiopathic epiretinal membranes formation. Practical medicine. 2018; (114): 71-76.

11. Kachalina GF, Doga AV, Kasmynina TA, Kuranova OI. Epiretinal fibrosis: pathogenesis, outcomes, treatment methods. Ophthalmosurgery. 2013; 4: 108-10.

12. Kuranova OI. The study of the effectiveness of micropulse laser irradiation with a wavelength of $577 \mathrm{~nm}$ in macular edema after surgical removal of idiopathic epiretinal membrane [dissertation]. 2014.

13. Bu S, Kuijer R, Li X, Hooymans J, Los L. Idiopathic epiretinal membrane. Retina. 2014; 34 (12): 2317-35.

14. Bolshunov AV. Questions of laser ophthalmology. M., 2013; 316.

15. Krasnov MM, Saprykin PI, Doronin PP, Nikolskaya GM, Akopyan VS, Mamedov NG. Electron-microscopic examination of the fundus tissue during laser coagulation. Bulletin of Ophthalmology. 1973; (2): 9-12.

16. Fedoruk NA, Fedorov AA, Bol'shunov AV. Morphological and histochemical effects of subthreshold laser therapy on the chorioretinal complex/ Bulletin of Ophthalmology. 2013; (5): 73-81.

17. Zheltov GI, Romanov GS, Romanov OG, Ivanova EV. Selective effect of laser pulses on the retinal pigment epithelium. Physical basis. New in ophthalmology. 2012; (3): 37-43.

18. Tahchidi HP, Kachalina GF, Kasmynina TA, Tebina EP. The method of combined laser treatment of the initial stage of epiretinal fibrosis RF № 2634684. 02.11.2017.

19. Zheltov Gl. Effect of intense optical radiation on eye tissue: research and applications. Extended abstract of candidate's thesis [dissertation]. 1996.

20. Zheltov Gl. Biophysics of the destructive action of the abovethreshold laser radiation on the fundus tissue. II All Russian seminar: "MAKULA 2006". Report in the conference proceedings. 2006; 71-85.

21. Jacobs S. Safety with Lasers and Other Optical Sources, by D. Sliney and M. Wolbarsht. Medical Physics. 1981; 8 (5): 725-6.

22. Karslow G, Eger D. Thermal conductivity of solids. M.: Science, 1964; 488

23. Linnik LA, Zheltov GI, Glazkov VN, Puhlik ES, Privalov AP. Change of energy thresholds of laser coagulation of retinal tissues with the age of patients. Ophthalmological journal. 1988; 6 (302): 355-8.

24. Zheltov $\mathrm{Gl}$. Effects of above-threshold laser radiation on the fundus tissue. Ophthalmology in Belarus. 2009; 3 (03): 24-40.

25. Barnes FS. Bological Damage Resulting from Thermal Pulses. In: Wolbarsht ML, Ed. Laser Application in Medicine and Biology. Ntw York: Plenum Press, 1984; 205-22.

26. Klepinina OB Subthreshold micropulse laser treatment with a wavelength of $577 \mathrm{~nm}$ in the treatment of central serous chorioretinopathy.Tambov, 2014; 61.

27. Romanov OG, Romanov GS, Zheltov Gl. Numerical modelling of photo-thermal and photo-mechanical effects in absorbing biological structures under action of short laser pulses Proceedings of SPIE. 2013; (8803). DOI: 10.1117/12.2032462

28. Zheltov G, Lisinetskii V, Grabtchikov A, Orlovich V. Low-threshold cavitation in water using IR laser pulse trains. Applied Optics. 2008; 47 (20): 3549-54.

29. Oraevsky A, Jacques S, Esenaliev R, Tittel F. Pulsed laser ablation of soft tissues, gels, and aqueous solutions at temperatures below $100{ }^{\circ} \mathrm{C}$. Lasers in Surgery and Medicine. 1996; 18 (3): 231-40.

\section{Литература}

1. Leask A, Abraham D. TGF- $\beta$ signaling and the fibrotic response. The FASEB Journal. 2004; 18 (7): 816-27.

2. Качалина Г. Ф., Касмынина Т. А., Иванова Е. В., Куранова О. И. Лазерное лечение транссудативной макулопатии, вызванной наличием эпиретинальной мембраны. Современные технологии лечения витреоретинальной патологии. В сборнике тезисов. ФГБУ «МНТК «Микрохирургия глаза». 2012; 94-6.

3. Patronas M, Kroll A, Lou P, Ryan E. A Review of Vitreoretinal Interface Pathology. International Ophthalmology Clinics. 2009; 49 (1): 133-43.

4. Пономерёва Е. Н., Казарян А. А. Структурно-фуннцциональные особенности макулярной зоны сетчатки при идиопатической эпиретинальной мембране. Российский офтальмологический журнал. 2013; (2): 66-9.

5. Guidry C. The role of Müller cells in fibrocontractive retinal disorders. Progress in Retinal and Eye Research. 2005; 24 (1): 75-86.

6. Harada C, Mitamura Y, Harada T. The role of cytokines and trophic factors in epiretinal membranes: Involvement of signal transduction in glial cells. Progress in Retinal and Eye Research. 2006; 25 (2): 149-64.

7. Zhao F, Gandorfer A, Haritoglou C, Scheler R, Schaumberger M, Kampik A, et al. Epiretinal Cell Proliferation in Macular Pucker and Vitreomacular Traction Syndrome. Retina. 2013; 33 (1): 77-88.

8. Joshi M, Agrawal S, Christoforidis J. Inflammatory Mechanisms of Idiopathic Epiretinal Membrane Formation. Mediators of Inflammation. 2013; (2013): 1-6.

9. Hinz B, Phan SH, Thannickal VJ, et al. The myofibroblast: one function, multiple origins. Am J Pathol. 2007; (170): 1807-16.

10. Захаров В. Д., Борзенок С. А., Горшком И. М., Колесник С. В., Колесник А. И., Миридонова А. В. Этиопатогенетические аспекты и роль структур витреоретинального интерфейса в формировании идиопатических эпиретинальных мембран. Практическая медицина. 2018; (114): 71-6.

11. Качалина Г. Ф., Дога А. В., Касмынина Т. А., Куранова О. И. Эпиретинальный фиброз: патогенез, исходы, способы лечения. Офтальмохирургия. 2013; (4): 108-10.

12. Куранова О. И. Изучение эффективности микроимпульсного лазерного воздействия длиной волны 577 нм при макулярном отеке после хирургического удаления идиопатической эпиретинальной мембраны [диссертация]. 2014.

13. Bu S, Kuijer R, Li X, Hooymans J, Los L. Idiopathic epiretinal membrane. Retina. 2014; 34 (12): 2317-35.

14. Большунов А. В. Вопросы лазерной офтальмологии. М., 2013; $316 \mathrm{c}$.

15. Краснов М. М., Сапрыкин П. И., Доронин П. П., Никольская Г. М., Акопян В. С., Мамедов Н. Г. Электронно-микроскопическое изучение тканей глазного дна при лазеркоагуляции. Вестник остальмологии. 1973; (2): 9-12.

16. Федорук Н. А., Федоров А. А., Большунов А. В. Морфологические и гистохимические особенности субпорогового лазерного воздействия на структуры хориоретинального комплекса. Вестник офтальмологии. 2013; (5): 73-81.

17. Желтов Г. И., Романов Г. С., Романов О. Г., Иванова Е. В. Селективное действие лазерных импульсов на ретинальный пигментный эпителий. Физические основы. Новое в офтальмологии. 2012; (3): 37-43. 
18. Тахчиди Х. П., Качалина Г. Ф., Касмынина Т. А., Тебина Е. П. Способ комбинированного лазерного лечения начальной стадии эпиретинального фиброза. Патент РФ №2634684. 02.11.2017.

19. Желтов Г. И. Воздействие интенсивного оптического излучения на ткани глаз: исследования и приложения [диссертация]. 1996.

20. Желтов Г. И. Биофизика деструктивного действия надпорогового лазерного излучения на ткани глазного дна. II Всероссийский семинар: «МАКУЛА 2006». Доклад в сборнике материалов конференции. 2006; 71-85.

21. Jacobs S. Safety with Lasers and Other Optical Sources, by D. Sliney and M. Wolbarsht. Medical Physics. 1981; 8 (5): 725-6.

22. Карслоу Г., Егер Д. Теплопроводность твердых тел. М.: Наука, 1964; 488.

23. ЛинникЛ.А., Желтов Г. И., Глазков В. Н. ПухликЕ. С., ПриваловА. П. Изменение энергетических порогов лазерокоагуляции тканей сетчатки с возрастом больных. Офтальмологический журнал. 1988; 6 (302), 355-8.

24. Желтов Г. И. Действие надпорогового лазерного излучения на ткани глазного дна. Офтальмология в Беларуси. 2009; 3 (03): 24-40.

25. Barnes FS. Bological Damage Resulting from Thermal Pulses. In: Wolbarsht ML, Ed. Laser Application in Medicine and Biology. Ntw York: Plenum Press, 1984; 205-22.

26. Клепинина О. Б. Субпороговое микроимпульсное лазерное воздействие длиной волны 577 нм при лечении центральной серозной хориоретинопатии. Тамбов, 2014; 61.

27. Romanov OG, Romanov GS, Zheltov Gl. Numerical modelling of photo-thermal and photo-mechanical effects in absorbing biological structures under action of short laser pulses Proceedings of SPIE. 2013; (8803). DOI: 10.1117/12.2032462.

28. Zheltov G, Lisinetskii V, Grabtchikov A, Orlovich V. Low-threshold cavitation in water using IR laser pulse trains. Applied Optics. 2008; 47 (20): 3549-54.

29. Oraevsky A, Jacques S, Esenaliev R, Tittel F. Pulsed laser ablation of soft tissues, gels, and aqueous solutions at temperatures below $100{ }^{\circ} \mathrm{C}$. Lasers in Surgery and Medicine. 1996; 18 (3): 231-40. 